\title{
GENE FLOW IN SCRUB JAYS: FREQUENCY AND DIRECTION OF MOVEMENT ${ }^{1}$
}

\author{
A. Townsend Peterson ${ }^{2}$ \\ Committee on Evolutionary Biology, The University of Chicago, Chicago, IL 60637 USA
}

\begin{abstract}
Based on strong differences in plumage coloration between coastal California (californica subspecies group) and Great Basin (woodhouseii subspecies group) populations of Scrub Jays (Aphelocoma coerulescens), museum specimens representing gene flow between the two forms are identified. A total of 27 examples of apparent genetic exchange between two forms (individuals of one subspecies group taken within the range of the other) is documented. Immigration rates are on the order of one per hundred or one per thousand individuals, a rate sufficient to prevent differentiation by genetic drift alone if effective population sizes are in the range of 100-550 individuals. Gene flow east-to-west across the Mojave Desert is two to seven times stronger than west-to-east movement. This directional bias has theoretical implications because an important assumption (symmetry of gene flow patterns) of most theoretical treatments of the effects of gene flow is violated. If effective population sizes are comparable in the two forms, then the bias in gene flow should lead to an overall greater rate of differentiation in the genetically more isolated woodhouseii populations.
\end{abstract}

Key words: Gene flow; population differentiation; dispersal; Corvidae; Scrub Jay.

\section{INTRODUCTION}

The importance of gene flow in preventing differentiation of populations has been debated extensively in recent decades (Mayr 1963; Ehrlich and Raven 1969; Endler 1973, 1977; Slatkin 1987). Some authors argue that gene flow is a critical constraint on the differentiation of populations (e.g., Mayr 1963), whereas others emphasize the importance of factors such as natural selection (e.g., Ehrlich and Raven 1969). The issue hinges critically on the overall magnitude of gene flow as it relates to historical factors, current ecological factors, and population structure and dynamics.

Actual measurements of levels of gene flow in natural populations, however, are relatively rare. Modes of estimation include direct techniques, such as studies of dispersal distances of marked individuals, and indirect techniques, such as the use of Wright's $F$-statistics or frequencies of "private" alleles (reviewed in Slatkin 1985b) derived from biochemical studies. When both approaches have been applied to the same species, they often produce very different results (Slatkin

\footnotetext{
${ }^{1}$ Received 18 February 1991. Final acceptance 2 July 1991 .

${ }_{2}^{2}$ Present address: Division of Birds, Field Museum of Natural History, Roosevelt Road at Lake Shore Drive, Chicago, IL 60605-2496.
}

1985a): indirect estimates are generally considerably higher than direct estimates, perhaps due to the effects of rare, long-distance dispersal, or due to the nonequilibrium nature of many natural populations. Nevertheless, the species for which both types of estimates exist are few, making evaluation of these techniques difficult.

Scrub Jays (Aphelocoma coerulescens) range from northern Oregon to southern Mexico, and from central Texas to the Pacific Ocean. Peripherally isolated populations are found on Santa Cruz Island off the coast of southern California, and in peninsular Florida (Pitelka 1951). The species is resident in oak woodland or pinyonjuniper woodland throughout much of its distribution, but ranges into other habitats in marginal areas (Peterson and Vargas, in press). Based on marked differentiation in morphology and plumage color, the species is divisible into five discrete "subspecies groups": the californica group (Oregon, California, and Baja California); the woodhouseii group (western Oregon and Wyoming south through the Great Basin and along the lower slopes of the Rocky Mountains and then along the Sierra Madre Oriental and Sierre Madre Occidental to central Mexico); the sumichrasti group (southern Mexico); the Florida populations; and the Santa Cruz Island population (Pitelka 1951). Each group is strikingly differentiated from all others in a number of plumage and morphological characters (Pitelka 1951). 
I have conducted genetic studies of the species using protein electrophoresis, documenting marked genetic differentiation among populations (Peterson 1990b). Within subspecies groups, populations are usually genetically similar, differing only in allozyme frequencies. Differences among subspecies groups, however, are stronger, often involving fixed allelic differences among populations. Hence, gene flow appears to be relatively strong on a local scale, but reduced on a regional scale (Peterson 1990b).

The purpose of this study is to estimate rates of genetic exchange between the coastal (californica) and interior (woodhouseii) groups of Scrub Jays directly from an independent source of data. Using the marked differentiation in plumage characters between the two forms, I am able to employ a somewhat novel approach to estimating rates of gene flow that focuses on long-distance gene flow. These estimates are then compared to those resulting from the genetic studies.

\section{STUDY AREA AND METHODS}

The californica and woodhouseii groups of Scrub Jays are separated from each other by a series of geographic barriers, chiefly deserts (Fig. 1). In the study area, californica populations are restricted to oak woodland and scattered patches of pinyon-juniper woodland, and woodhouseii populations range in the pinyon-juniper, pinyonjuniper-oak and oak woodlands of Nevada and Arizona. In the northern Great Basin, californica populations are distributed in pine-oak and riparian woodlands south to the vicinity of Lake Tahoe; woodhouseii populations are 100-150 km distant across the deserts of northwestern Nevada in scattered desert mountain ranges. Farther south, the two forms approach one another closely (to about $20 \mathrm{~km}$ ) in the Owens Valley of eastern California: californica populations are in the pinyon and riparian woodlands on the west wall, whereas woodhouseii populations are in the pinyon-juniper woodlands high in the White and Inyo mountains that form the east wall of the valley. Finally, in southern California, the two forms are separated by wide expanses $(100 \mathrm{~km}$ or more) of open desert (the Mojave and Colorado River deserts).

The two Scrub Jay forms differ strikingly in a number of features. Overall, californica jays are deep blue (approaching purplish in southern California) dorsally and clean white ventrally, whereas woodhouseii jays are light gray-blue dorsally and smoky gray ventrally. In addition, californica jays have a pronounced blue collar (lacking in woodhouseil jays), a brown back (bluegray in woodhouseii jays), whitish or grayish under-tail coverts (blue in woodhouseii jays), and a hooked bill (generally straighter in woodhouseii jays; Pitelka 1951).

I evaluated a total of 2,647 specimens from the study area. I either visited or borrowed specimens from 22 museum collections: Academy of Natural Sciences of Philadelphia (ANSP), A. R. Phillips' private collection in Monterrey, Mexico (ARP), American Museum of Natural History, California State University at Long Beach (CSULB), Carnegie Museum of Natural History, Chicago Academy of Sciences (ChicASci), Delaware Museum of Natural History, Field Museum of Natural History (FMNH), Harvard University Museum of Comparative Zoology, Instituto de Biologia of the Universidad Nacional Autónoma de México, Los Angeles County Museum of Natural History (LACM), Louisiana State University Museum of Natural Science, Museo de Zoología of the Facultad de Ciencias of the Universidad Nacional Autónoma de México, Museum of Vertebrate Zoology of the University of California at Berkeley (MVZ), Nevada State Museum (NSM), San Bernardino County Museum of Natural History (SBCM), University of California at Los Angeles (UCLA), University of Michigan Museum of Zoology (UMMZ), University of Nevada at Reno, U.S. National Museum of Natural History (USNM), Western Foundation of Vertebrate Zoology, and the Yale Peabody Museum. A few additional records were included based on information provided by the San Diego County Museum of Natural History (SD).

Each specimen was identified to subspecies or at least to subspecies group, and label data recorded. Collection localities were later grouped for analysis as follows. The study area was divided into six two-degree latitudinal bands on either side of the desert barrier (WW1-6, EE1-6; Fig. 1): these served as the major "source areas" for analysis. Additionally, specimens from 13 areas immediately adjacent to the desert barrier (WZ1-9, EZ1-4), and four desert zones (D1-4) were included in the analysis (Fig. 1).

Rates of gene flow were calculated as the proportion of the total sample from a region that showed influence from the other subspecies group. To the extent that strange individuals were se- 


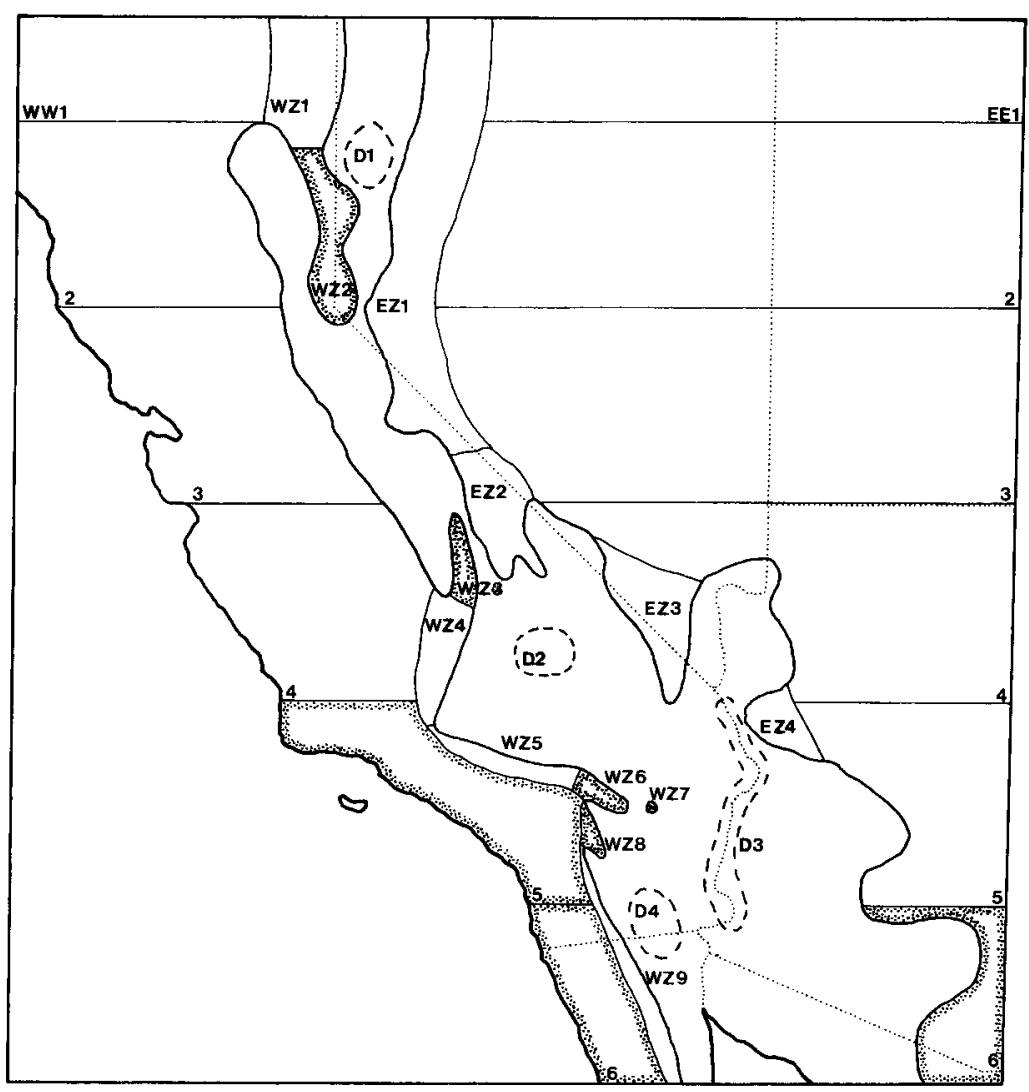

FIGURE 1. Map of the study area showing the ranges of the californica and woodhouseii groups of Scrub Jays, the sampling regions employed in this study, and the occurrence of immigrant individuals in each region (stippled areas).

lectively collected, these estimates may represent an upper bound on actual rates. These individuals were further divided into "pure" (i.e., putative first-generation immigrants) and "mixed" (apparent products of hybridization between the two forms) individuals, based on the plumage and morphological characters described above (Pitelka 1951).

\section{RESULTS}

Specimens representing immigrants or intergrades are summarized in the Appendix. Eight individuals apparently represent actual first-generation immigrants; of these, seven are woodhouseii jays (subspecies nevadae) collected in California, and one is a californica jay (subspecies obscura) collected in southern Arizona. Nineteen additional specimens appear to be intergrades because their plumages are either in- termediate or a mixture of traits of the two forms. All intergrades were found west of the desert barrier among californica populations.

Rates of immigration (as indexed by proportional representation of immigrants or intergrades) differ strongly between the two subspecies groups (Table 1). Several californica samples include a large number of apparent immigrants: proportional representation is as high as $4.7 \%$ in populations east of the northern Sierra Nevada, $7.5 \%$ in the Little San Bernardino Mountains of southern California, and $16.0 \%$ along the west wall of the Owens Valley. All three specimens available from Eagle Mountain in southern California are apparent intergrades (Peterson 1990a). In contrast, only one apparent immigrant was found among all 546 woodhouseii specimens examined. The overall proportion of immigrants and intergrades is $1.25 \times 10^{-2}$ in californica populations, and $1.83 \times 10^{-3}$ in woodhouseii pop- 
TABLE 1. Summary of sample sizes in each region and proportional levels of gene flow. $P$ indicates apparently pure (first-generation) immigrants; $M$ indicates individuals showing a mixture of traits of interior and coastal populations.

\begin{tabular}{|c|c|c|c|c|}
\hline Region & Description & $\begin{array}{l}\text { Total } \\
\text { immigrants }\end{array}$ & $\begin{array}{c}\text { Sample } \\
\text { size }\end{array}$ & Proportion \\
\hline WW1 & Northernmost California & 0 & 33 & 0.0 \\
\hline WW2 & Northern California & 0 & 146 & 0.0 \\
\hline WW3 & Central California & 0 & 568 & 0.0 \\
\hline WW4 & Central-southern California & 0 & 211 & 0.0 \\
\hline WW5 & Los Angeles area & $1(\mathrm{P})$ & 328 & $3.05 \times 10^{-3}$ \\
\hline \multirow[t]{2}{*}{ WW6 } & Southernmost California and northern & & & \\
\hline & Baja California & $1 ?(\mathrm{P})$ & 204 & $4.90 \times 10^{-3}$ \\
\hline WZ1 & Northeastern California & 0 & 72 & 0.0 \\
\hline WZ2 & East of Sierra Nevada & $4(2 \mathrm{P}, 2 \mathrm{M})$ & 85 & $4.71 \times 10^{-2}$ \\
\hline WZ3 & Owens Valley & $8(2 \mathrm{P}, 6 \mathrm{M})$ & 50 & 0.16 \\
\hline WZ4 & Kern County & 0 & 48 & 0.0 \\
\hline \multirow[t]{2}{*}{ WZ5 } & North Slope, San Gabriel and San & & & \\
\hline & Bernardino Mountains & 0 & 71 & 0.0 \\
\hline WZ6 & Little San Bernardino Mountains & $8(1 \mathrm{P}, 7 \mathrm{M})$ & 107 & $7.48 \times 10^{-2}$ \\
\hline WZ7 & Eagle Mountain & $3(3 \mathrm{M})$ & 3 & 1.0 \\
\hline WZ8 & Desert-edge ranges, Southern California & $1(\mathrm{M})$ & 102 & $980 \times 10^{-3}$ \\
\hline \multirow[t]{2}{*}{ WZ9 } & Sierra de Juárez and Sierra San & & & \\
\hline & Pedro Martir, Baja California & 0 & 56 & 0.0 \\
\hline EZ1 & Western Nevada & 0 & 9 & 0.0 \\
\hline EZ2 & White-Inyo and Death Valley Ranges & 0 & 104 & 0.0 \\
\hline EZ3 & Southern Nevada, East Mojave & 0 & 97 & 0.0 \\
\hline EZ4 & Hualapai Mountains & 0 & 4 & 0.0 \\
\hline EE 1 & Northernmost Nevada & 0 & 2 & 0.0 \\
\hline EE2 & North-central Nevada & 0 & $5 \overline{1}$ & 0.0 \\
\hline EE3 & South-central Nevada & 0 & 23 & 0.0 \\
\hline EE4 & Southern Nevada, Northern Arizona & 0 & 43 & 0.0 \\
\hline EE5 & Central Arizona & 0 & 71 & 0.0 \\
\hline EE6 & Southern Arizona & $1(\mathrm{P})$ & 142 & $7.04 \times 10^{-3}$ \\
\hline
\end{tabular}

ulations. The difference between the two populations is statistically significant (poisson distribution, $\mu=6.81, n=546, \mathrm{X}=1, P<$ 0.008).

Seventeen specimens collected from the intervening deserts represent wandering individuals rather than resident populations (Pitelka 1951; Table 2). Four specimens (three nevadae, one representing an undetermined californica group population), have been collected from the desert lowlands of the Owens Valley. Single specimens (both nevadae) have been taken from Harper Dry Lake in San Bernardino County (E. Cardiff, pers. comm.) and the Salton Sea (P. Unitt, pers. comm.). Eleven individuals (10 nevadae, one californica not identified to subspecies) have been collected from along the Colorado River. All of these wandering individuals are subadults (second year), a trend pointed out previously by $\mathrm{Pi}-$ telka $(1945,1951)$. Once again, a directional bias is evident, both in the Colorado River sample and in all 17 individuals: vagrants from the east

TABLE 2. Summary of origin of individuals collected in intermediate areas.

\begin{tabular}{lccc}
\hline \multicolumn{1}{c}{ Locality } & Western & Eastern & Significance \\
\hline CA, Inyo Co., Owens Valley & 1 & 3 & - \\
CA, San Bernardino Co., Harper Dry Lake & 0 & 1 & - \\
CA/AZ, Colorado River & 1 & 10 & $P \leq 0.001$ \\
CA, Salton Sea & 0 & 1 & - \\
TOTAL & 2 & 15 & $P \leq 0.001$ \\
\hline
\end{tabular}


greatly outnumber those from the west (Table 2; sign tests, $P \leq 0.001$ ).

As described above, the overall proportion of individuals showing influence from populations of the "other" subspecies group is $1.25 \times 10^{-2}$ in californica populations, and $1.83 \times 10^{-3}$ in woodhouseii populations. For estimates of actual gene flow, these figures perhaps should be adjusted to include only actual immigrants rather than any individual showing influence of the other form. Hence, because only 7 of 2,084 individuals from californica populations are pure nevadae, a revised, minimum estimate of rate of gene flow would be $3.36 \times 10^{-3}$. The estimate for woodhouseii populations needs no adjustment because the one californica group individual found is apparently a first-generation immigrant.

\section{DISCUSSION}

\section{POSSIBLE PROBLEMS}

Four potential sources of error in interpretation of the above data must be considered. First, errors on specimen labels may have produced apparent examples of gene flow. Especially on older specimens, locality data are occasionally vague or misleading. However, in 18 of the 44 cases, I or others (F. A. Pitelka, pers. comm.) have personally verified the locality with the actual collector. For another 12 examples, evidence from field notes and other specimens collected strongly indicates that the records are indeed accurate. Hence, although label errors might account for some of the supposed examples of gene flow, at least 30 of the 44 cases are unlikely to be due to label error.

A potentially more serious problem is that the examples of gene flow, especially specimens identified as intergrades, might simply be extreme variants rather than examples of gene flow. I consider this unlikely for two reasons. First, intergrades invariably show influence of the other subspecies group in several characters; e.g., an individual that is exceptionally light gray dorsally in a californica population almost invariably has a straight bill, an indistinct collar, and bluish under-tail coverts. If these characters are segregating independently, such a correlation in their occurrence would not be expected. Second, intergrades are concentrated in the three areas most likely to receive genetic input from wood- houseii populations; no intergrades were detected in coastal areas remote from interior populations. A similar complication is that the "immigrants" might actually be carrying a rare primitive allele that resembles the other form; I consider this unlikely for the same two reasons as for the "extreme variant" problem.

Third, true gene flow must be distinguished from the simple presence of vagrants that are unable to obtain mates and breed (i.e., reproductive isolation). It appears that immigrant Scrub Jays are able to breed, given that at least one (MVZ 84947) had a well-developed brood patch and was feeding young when collected. The presence of numerous intergrades indicates that offspring of such breeding attempts do survive to maturity and breed themselves.

Finally, it is possible that these rate estimates are inflated due to selective shooting of strange (i.e., immigrant) individuals. Based on conversations with several of the collectors and on personal experience collecting Scrub Jays, I believe this possibility to be unlikely: although the characters differentiating the two forms are obvious in the hand, they are difficult to see in the field. Hence, for instance, in the series of nearly 50 specimens collected by Pitelka and his field teams in the Owens Valley (Pitelka 1951), I doubt that immigrants or intergrades were selectively shot.

\section{DIRECTIONAL BIAS}

Gene flow documented in this study is strongly biased toward east-west, rather than west-east, movement. The bias in Scrub Jays appears to be part of a trend in many species. Miller and Stebbins (1964) and Peterson (1990a) argued for ongoing or historical gene flow from the Great Basin in two or three species resident on Eagle Mountain in southern California. Johnson and Garrett (1974) documented expansions of breeding range from the east into southern California by eight species. Additional examples of this trend can be found in Miller (1947) and recent issues of American Birds, but little evidence exists for gene flow or range expansion in the reverse direction. Hence, the east-west bias in gene flow may be more general than in just Scrub Jays.

In Scrub Jays, a reason for the bias seems evident. Californica jays live almost exclusively in oak woodlands, whereas woodhouseii jays live mostly in pinyon-juniper woodlands (Pitelka 1951, Peterson and Vargas, in press). Because 
pinyon-juniper woodland seems to grade directly into desert habitats, but oak woodland tends to be more separated spatially and distinct structurally from desert, I believe that a stronger psychological barrier to entering desert habitats exists for californica jays. Other reasons might include differences in temporal stability of nut crops or availability of breeding space in the two habitats.

The directional bias in gene flow has implications for theoretical treatments. In discretesubpopulation migration models, genetic interchange among subpopulations is usually summarized in a migration matrix. Migration matrices, however can take two forms: the "backward" matrix $M_{i j}$ summarizes the proportion of individuals in population $i$ that immigrated from population $j$, whereas the "forward" matrix $M^{*}{ }_{i j}$ gives the proportion of offspring in population $i$ in one generation that will breed in population $j$ in the next generation (Slatkin 1985a). For mathematical simplicity, theoretical treatments commonly assume symmetry of gene flow, i.e., that $M_{i j}=M^{*}{ }_{i j}$ (Slatkin 1985a). This assumption is clearly not satisfied in the case of Scrub Jays, and if such directional biases are common in other natural populations, the applicability of treatments based on this assumption may need to be reevaluated.

\section{RATES OF GENE FLOW}

Calculations of rates of gene flow based on all californica populations suggest that $0.34-1.25 \%$ of the population represent immigrants or intergrades. Considering only the desert-edge populations, genetic interchange is strong. In the populations of the west wall of the Owens Valley, $16 \%$ of individuals show eastern influence, and $4 \%$ are apparently first-generation immigrants (Pitelka 1951). The isolated population of Eagle Mountain in southern California appears to be a mixture of the two forms, either through hybridization or due to historical intermediacy (Peterson 1990a). In woodhouseii populations, $0.18 \%$ of individuals are apparent immigrants. Hence, genetic exchange between the two subspecies groups occurs at appreciable frequencies.

The effects of gene flow can be best understood in conjunction with information on effective population sizes: if the product of the immigration rate $m$ and effective population size $N$ exceeds one, then differentiation by genetic drift alone is unlikely (Wright 1931, Slatkin 1985a). Unfortunately, precise estimates of effective population sizes are unavailable for western North American Scrub Jays, or in fact for almost any bird species. Based on estimates of dispersal distances and population densities for Florida Scrub Jays, Woolfenden and Fitzpatrick (1984) estimated an effective population size of 298 individuals; incorporation of the effects of variance in reproductive success reduces the estimate to 20-40 individuals (J. W. Fitzpatrick, pers. comm.). These estimates are of little use in the present study, however, because the Florida population has a social system characterized by dispersal profiles very different from those of western populations (Woolfenden and Fitzpatrick 1984). Because of long dispersal distances in western Scrub Jay populations (D. B. Burt, pers. comm.; W. Carmen, pers. comm.; C. T. Collins, pers. comm.; M. J. Elpers, pers. comm.), it is almost certain that effective population sizes in western Scrub Jay populations are much higher than those of Florida Scrub Jays.

However, because of the disparity of immigration rates for californica and woodhouseii populations, an interesting situation exists (Fig. 2). If effective population sizes fall in the approximate range $100-550$, then woodhouseii populations should be able to differentiate from the ancestral state by genetic drift (based on the estimate of $m$ for woodhouseii populations), but californica populations should not (based on minimum and maximum estimates of $m$ for $\mathrm{cal}$ ifornica populations). In other words, if effective population sizes are similar in the two groups (an assumption that should be tested), due to the asymmetry of gene flow between the two subspecies groups, the rate of differentiation from the ancestral state should be higher in woodhouseii populations than in californica populations. This prediction, however, does not seem to be borne out in preliminary analyses of rates of molecular evolution (Peterson 1990b, in prep.).

Based on electrophoretic studies of 10 californica, 11 woodhouseii, and 2 sumichrasti populations of Scrub Jays (Peterson 1990b), I estimated the gene flow parameter $\mathrm{Nm}$ at 4.166 using the private alleles method of Slatkin (1985b). Unfortunately, because these indirect methods are unable to separate $N$ and $m$, direct comparison is difficult. Nonetheless, the direct and indirect estimates are comparable if effective pop- 


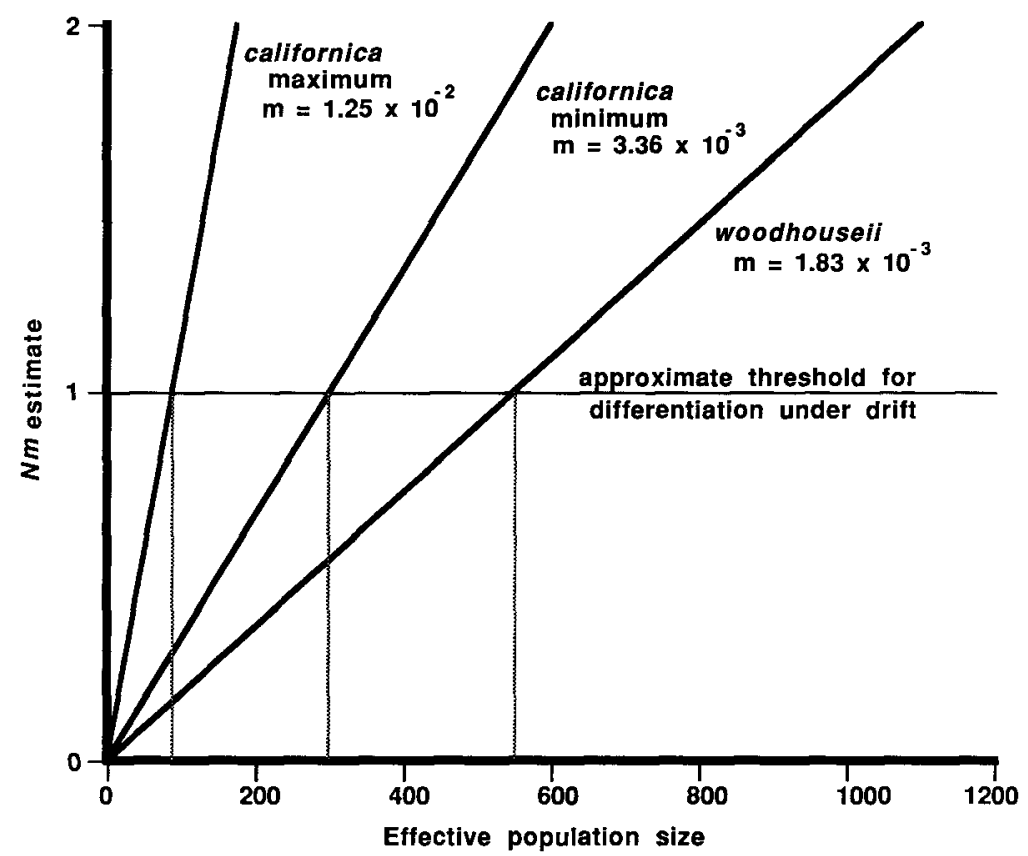

FIGURE 2. Possible combinations of effective population sizes $N$ and immigration rates $m$. Approximate conditions for differentiation under genetic drift alone $(N m<1)$ are shown, and the dotted lines indicate threshold effective population sizes for differentiation by drift alone based on the estimates of $m$ produced in this study.

ulation sizes fall in the range 333-2,274 individuals.

\section{CONCLUSIONS}

In the present study, the rate and directionality of gene flow between two differentiated forms of Scrub Jays is documented. Immigration rates in the two forms are $0.2-1.2 \%$; these rates are sufficient to prevent differentiation of both forms by genetic drift alone if effective population sizes exceed about 550 individuals (Wright 1931). Movement east-to-west across the Mojave Desert is two to seven times greater than west-toeast movement. This directional bias has theoretical implications because an important assumption (directional symmetry of gene flow) of most theoretical treatments of the subject is violated. Finally, if effective population sizes are comparable, the biased gene flow should lead to an overall greater rate of differentiation in woodhouseil populations, but this prediction is not supported in preliminary tests. This study serves to emphasize the importance of continued collecting even in well-known areas such as the United States, especially of vagrants and where long, single-locality series can be prepared.

\section{ACKNOWLEDGMENTS}

I thank the curators and collection managers of the 23 museum collections listed in the Methods section for their generous assistance with information requests, loans, and visits, especially Charles Collins for his generous interest in my study of the long series of Scrub Jays under his care. Thanks to the Field Museum of Natural History for providing facilities for borrowing and studying several hundred specimens. Thanks to Eugene Cardiff and Phil Unitt for providing important information on Scrub Jay distribution in the study area, and to J. Van Remsen, John Bates, and Andrew Kratter for critical review of the manuscript. My warmest thanks to Frank Pitelka and John Fitzpatrick for their interest and encouragement throughout. This study was supported by the National Science Foundation Dissertation Improvement Program, National Geographic Society, Field Museum of Natural History, Hinds Fund of the University of Chicago, Sigma Xi, and the Chapman Fund of the American Museum of Natural History.

\section{LITERATURE CITED}

EhrLICH, P. R., AND P. H. Raven. 1969. Differentiation of populations. Science 165:1228-1232.

ENDLER, J. A. 1977. Geographic variation, speciation, and clines. Princeton Univ. Press, Princeton, NJ.

ENDLER, J. A. 1973. Gene flow and population differentiation. Science 179:243-250. 
Johnson, N. K., AND K. L. GarretT. 1974. Interior bird species expand breeding ranges into southern California. Western Birds 5:45-56.

Mayr, E. 1963. Animal species and evolution. Belknap Press, Cambridge, MA.

Miller, A. H. 1947. Arizona race of Acorn Woodpecker vagrant in California. Condor 49:171.

Miller, A. H., AND R. C. Stebbins. 1964. The lives of desert animals in Joshua Tree National Monument. Univ. Calif. Press, Berkeley, CA.

Peterson, A. T. 1990a. Birds of Eagle Mountain, Joshua Tree National Monument, California. Western Birds.

Peterson, A. T. 1990b. Evolutionary relationships of the Aphelocoma jays. Ph.D.diss., Univ. of Chicago, Chicago.

Peterson, A. T., ANd N. Vargas B. In press. Ecological diversity in Scrub Jays (Aphelocoma coe- rulescens). In T. P. Ramamoorthy, J. Fa, and R. Bye, [eds.], The biological diversity of Mexico Oxford Univ. Press, Oxford, England.

Pitelka, F. A. 1945. Pterylography, molt, and age determination of American jays of the genus Aphelocoma. Condor 47:229-260.

Pitelka, F. A. 1951. Speciation and ecologic distribution in American jays of the genus Aphelocoma. Univ. Calif. Publ. Zool. 50:195-464.

Slatkin, M. 1985a. Gene flow in natural populations. Ann. Rev. Ecol. Syst. 16:393-430.

SLAtKin, M. 1985b. Rare alleles as indicators of gene flow. Evolution 39:53-65.

SlatKIN, M. 1987. Gene flow and the geographic structure of natural populations. Science $236: 787-$ 792.

WrIGHT, S. 1931. Evolution in Mendelian populations. Genetics 16:97-159. 
APPENDIX. Summary of examples of gene flow between coastal and interior Scrub Jay populations.

\begin{tabular}{|c|c|c|}
\hline Locality & Museum no./ref. & Description \\
\hline \multicolumn{3}{|l|}{ East-west movement } \\
\hline NV, Granite Mountains & USNM 139709 & pure nevadae \\
\hline NV, Sutcliffe & LACM 22431 & pure nevadae \\
\hline $\begin{array}{l}\text { NV, Ormsby Co., Kings } \\
\text { Cyn. }\end{array}$ & NSM 1050 & juvenile with bluish chest as in nevadae \\
\hline NV, Reno & USNM 531739 & as nevadae in color of chest and belly \\
\hline NV, Gardnerville & MVZ 118704-6 & towards nevadae \\
\hline \multirow{8}{*}{$\begin{array}{l}\text { CA, Inyo Co., west wall, } \\
\text { Owens Valley }\end{array}$} & MVZ 22504 & pure nevadae (Pitelka 1951) \\
\hline & MVZ 20077 & pure nevadae (Pitelka 1951) \\
\hline & MVZ 84936 & intermediate (Pitelka 1951) \\
\hline & MVZ 84970 & intermediate (Pitelka 1951) \\
\hline & MVZ 20068 & intermediate (Pitelka 1951) \\
\hline & MVZ 84952 & intermediate (Pitelka 1951) \\
\hline & MVZ 84946 & intermediate (Pitelka 1951) \\
\hline & MVZ 84950 & intermediate (Pitelka 1951) \\
\hline $\begin{array}{l}\text { CA, Riverside Co., } \\
\text { J.T.N.M., Lower Coving- } \\
\text { ton Flats }\end{array}$ & CSULB 3807 & as nevadae in straight beak, blue of pileum \\
\hline \multirow{2}{*}{$\begin{array}{l}\text { CA, Riverside Co., } \\
\text { J.T.N.M., Upper Coving- } \\
\text { ton Flats }\end{array}$} & CSULB 3825 & pure nevadae \\
\hline & CSULB 3852 & apparent $F 1$ hybrid \\
\hline \multirow{3}{*}{$\begin{array}{l}\text { CA, Riverside Co., } \\
\text { J.T.N.M., Eagle Moun- } \\
\text { tain }\end{array}$} & MVZ 94204 & intermediate in several characters (Pitelka 1951) \\
\hline & MVZ 94205 & intermediate in several characters (Pitelka 1951) \\
\hline & MVZ 93535 & intermediate in several characters (Pitelka 1951) \\
\hline \multirow{2}{*}{$\begin{array}{l}\text { CA, Riverside Co., Cole- } \\
\text { man Tin Mine }\end{array}$} & CSULB 623 & as nevadae in blue of pileum \\
\hline & CSULB 642 & as nevadae in blue of pileum and gray breast \\
\hline CA, Colton & ANSP 27922 & pure nevadae \\
\hline $\begin{array}{l}\text { CA, San Diego or San Ber- } \\
\text { nardino }\end{array}$ & ANSP 33854 & pure nevadae, but tag possibly inaccurate \\
\hline Baja Calif. Norte, Alaska & Pitelka 1951 & intermediate \\
\hline \multicolumn{3}{|l|}{ West-east movement } \\
\hline AZ, Dos Cabezos [sic] & ChicASci 394 & pure obscura \\
\hline \multicolumn{3}{|l|}{ Intermediate areas } \\
\hline \multirow{4}{*}{$\begin{array}{l}\text { CA, Inyo Co., Owens Val- } \\
\text { ley }\end{array}$} & UCLA K786 & nevadae \\
\hline & UCLA K789 & nevadae \\
\hline & UMMZ 129341 & nevadae \\
\hline & USNM 139602 & californica group \\
\hline $\begin{array}{l}\text { CA, San Bernardino Co., } \\
\text { Harper Dry Lake }\end{array}$ & E. Cardiff, pers. comm. & nevadae \\
\hline \multirow{11}{*}{ CA/AZ, Colorado River } & LACM 46037 & nevadae \\
\hline & SBCoMNH 36420 & nevadae \\
\hline & USNM 393492 & nevadae \\
\hline & ARP 163 & nevadae \\
\hline & ARP 819 & nevadae \\
\hline & MVZ 146111 & nevadae \\
\hline & MVZ 146112 & nevadae \\
\hline & SDCoMNH 22173 & nevadae \\
\hline & SDCoMNH 32174 & nevadae \\
\hline & SDCoMNH 11318 & nevadae \\
\hline & USNM 2841 & californica group \\
\hline CA, Salton Sea & P. Unitt, pers. comm. & nevadae \\
\hline
\end{tabular}

